\title{
Montaigne, Florio and Shakespeare: the mediation of colonial discourse
}

Philip Hendrick

\author{
(2) OpenEdition \\ Journals \\ Édition électronique \\ URL : http://journals.openedition.org/shakespeare/164 \\ DOI : 10.4000/shakespeare.164 \\ ISSN : 2271-6424 \\ Éditeur \\ Société Française Shakespeare \\ Édition imprimée \\ Date de publication : 1 novembre 2004 \\ Pagination : 117-133 \\ ISBN : 2-9521475-0-7
}

\section{Référence électronique}

Philip Hendrick, « Montaigne, Florio and Shakespeare: the mediation of colonial discourse », Actes des congrès de la Société française Shakespeare [En ligne], 21 | 2004, mis en ligne le 31 janvier 2007, consulté le 06 mai 2019. URL : http://journals.openedition.org/shakespeare/164 ; DOI : 10.4000/ shakespeare.164 


\section{Shakespeare et Montaigne vers un nouvel humanisme}

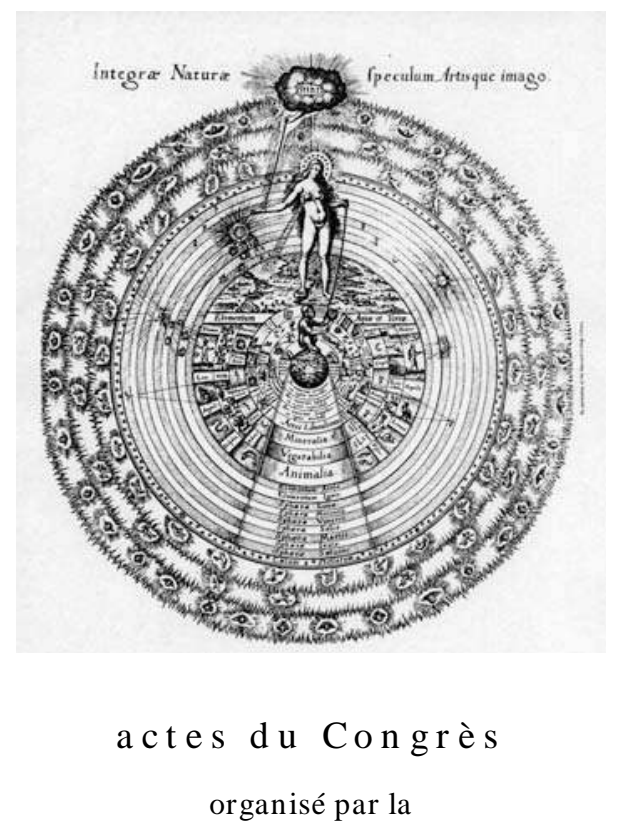

SOCIÉTÉ FR ANÇAISE SH AKESPEARE en collaboration avec la

S OC I É T É I N T E R N A T I O N A L E DES AM I D E M O N A I G N les 13,14 et 15 mars 2003

$$
\begin{gathered}
\text { textes réunis par } \\
\text { Pierre KAPITANIAK } \\
\text { sous la direction de } \\
\text { Jean-Marie MAGUIN }
\end{gathered}
$$




\section{COMITÉ SCIENTIFIQUE :}

Margaret Jones-Davis

Gisèle Venet

Jean-Marie Maguin

Yves Peyré

François Laroque

Pierre Kapitaniak

\section{COUVERTURE :}

Robert Fludd

Utriusque Cosmi Historia (1617-19)

planche 17

conception graphique et logo

Pierre Kapitaniak

\section{(C) 2003 Société Française Shakespeare}

Institut du Monde Anglophone

Université de Paris III - Sorbonne Nouvelle

http:// univ-montp3.fr/SFS/

5 rue de l'École de Médecine

75006 Paris

Diffusion :

AVL DIFFUSION

Parc Euromédecine

34198 MONTPELLIER CEDEX 5

ISBN 2-9521475-0-7

Tous droits de traduction, de reproduction et d'adaptation réservés pour tous les pays 


\title{
MONTAIGNe, FLORIO AND SHAKESPEARE: THE MEDIATION OF COLONIAL DISCOURSE
}

\author{
Philip HENDRICK
}

\begin{abstract}
This paper looks in detail at those sections of Florio's translation of Des Cannibales that may have had an influence on The Tempest. Recent Shakespeare criticism has debated the question of colonialist discourse in the play. On the other hand, recent interpretations of Des Cannibales emphasise the richness and complexity of Montaigne's approach to the question of colonisation. Florio's translation has been generally praised for its colour, its verve and its reflection of aspects of the style of Montaigne. It also expresses some ideas that were commonly held in Elizabethan England, but which were not in the original Montaigne text. While all translations interpret, modify and sometimes falsify the text translated, Florio appears at first sight to follow the text of the Essais with great fidelity. However, close analysis of his translation reveals that in some questions, particularly the issue of colonialism, Florio imposes his own perspectives, assumptions and values on the essay being translated. The question of Shakespeare's "debt" to Montaigne, and the question of colonialist discourse in The Tempest, may therefore be more properly seen as his debt to Florio.
\end{abstract}

Montaigne, Florio et Shakespeare: la médiation du discours colonialiste Cette étude analyse en détail les sections de la traduction de l'essai Des Cannibales par Florio qui ont pu avoir une influence sur La Tempête. De récentes critiques de Shakespeare ont débattu de la question du discours colonialiste de la pièce. D'autre part, des interprétations récentes de l'essai Des Cannibales mettent l'accent sur la richesse et la complexité de l'approche de Montaigne en ce qui concerne la question de la colonisation. On a souvent fait l'éloge de la traduction de Florio pour sa couleur, sa verve et son écho du style de Montaigne. Elle exprime également certaines idées qui avaient cours dans l'Angleterre élisabéthaine mais qui ne se trouvaient pas dans le texte original de Montaigne. Tandis que toutes les traductions interprètent, modifient et parfois falsifient le texte traduit, Florio semble à première vue suivre le texte des Essais avec une grande fidélité. Toutefois, une analyse attentive de sa traduction révèle que concernant certaines questions en particulier celle du colonialisme, Florio impose ses propres perspectives, suppositions et valeurs à l'essai qu'il traduit. La question de la "dette " de Shakespeare à Montaigne, et du discours colonialiste dans La Tempête, peut ainsi être plus justement considérée comme sa dette à Florio.

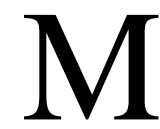

ontaigne's Des Cannibales and Shakespeare's The Tempest have both been studied in depth in recent years. Some very fine studies of both texts have appeared, and there is a growing awareness of the richness and relevance of each to contemporary social and political issues. Shakespeare Studies have had a lively debate on whether The Tempest is a contribution to "colonial discourse". The most recent Arden edition of the play, for example states that "The extensive and varied discourses of colonialism, many critics argue, are deeply embedded in the drama's language and events". ${ }^{188}$ Many have claimed that the Prospero-Caliban relationship mirrors the European-Native American relationship of the early $17^{\text {th }}$

188 The Tempest, ed. Virginia Mason Vaughan and Alden T. Vaughan, Arden, 1999, p. 39. 
century, and that Shakespeare unconsciously adopts colonial values in the play. ${ }^{189}$ These so-called revisionist interpretations have in their turn been criticised by others, most notably Meredith Anne Skura, for focussing too narrowly on the political dimension of the play. ${ }^{190}$ In Montaigne studies, there have been many excellent analyses of Des Cannibales. Each has in its own way opened out new perspectives on this extraordinary essay, and shown how rich and diverse the text is in its resonances with contemporary politics and society. ${ }^{191}$ There have also been studies of the relationship between other essays by Montaigne and Shakespeare's play, most notably that of Arthur Kirsch, in which he expands on the number of cross references from one to the other, and the influential article by Robert Ellrodt, which examines different aspects of the relationship between the two writers. ${ }^{192}$

I intend to examine some of the major issues that are raised in these different interpretations. In particular I will analyse the extracts from the "Montaigne/Florio" texts that are quoted in them, and try to determine whether the quotations from the Florio version of the Essais can be seen as authentic reflections of Montaigne's thought, or whether, on the other hand, the vivid imagination of John Florio plays a part in the transmission of a modified version of Montaigne's original text, thereby mediating a modified version of his thoughts on colonialism, art and nature.

The Florio translation has itself been the subject of some good general studies. Matthiessen, in his Translation: an Elizabethan Art, states that "the first thing that strikes the reader of his translation is his

189 See particularly Paul Brown, “This thing of darkness I acknowledge mine': The Tempest and the discourse of colonialism", Political Shakespeare: New Essays in Cultural Materialism, Cornell University Press, 1985, p. 48-71; Barker, Francis; Hulme, Peter. 'Nymphs and reapers heavily vanish: the discursive con-texts of The Tempest', Alternative Shakespeares, ed. John Drakakis, London, Methuen, 1985, p. 191-205.

190 Meredith Anne Skura, "Discourse and the Individual: the case of Colonialism in The Tempest," Shakespeare Quarterly 40, 1 (Spring 1989) p. 42-69.

${ }^{191}$ See particularly Gérard Defaux, "Un Cannibale en haut de chausses: Montaigne, la différence et la logique de l'identité", Modern Language Notes 97 (1982) p. 918-57; Frank Lestringant, "Le Cannibalisme des Cannibales", BSAM 9-10 (1982) p. 27-40 and 11-12 (1982) p. 19-38; André Tournon, Montaigne, La Glose et l'Essai, Presses Universitaires de Lyon, 1983, p. 217-221; Philippe Desan, Montaigne, les Cannibales et les Conquistadores, Paris, Nizet, 1994; and George Hoffmann, "Anatomy of the Mass: Montaigne's 'Cannibals", PMLA, Volume 117 No 2 (March 2002) p. 207-221.

192 Arthur Kirsch, "Virtue, Vice and Compassion in Montaigne and The Tempest", Studies in English Literature, 37 (1977) p. 337-52; Robert Ellrodt, "Self-consciousness in Montaigne and Shakespeare", Shakespeare Survey 28 (1975) p. 37-50. 
passionate delight in words". ${ }^{193}$ And there are numerous examples where Florio quite simply adds words in order to heighten a situation by emphasis. In the same vein, the translator uses doubling extensively, as Matthiessen suggests, both "to decorate his style and to make the meaning fuller for his English reader". ${ }^{194}$ Apart from obvious mistakes, made probably through haste and inattention rather than ignorance, the translation attempts to explain cultural references to the English reader, and there is an amusing list drawn up by Matthiessen:

Florio shares the Elizabethan love of horses; he detests Catholics and poetasters; he approves of sport and disapproves of whores. And when a passage in Montaigne gives him an excuse for expressing an opinion or indulging his tastes, he is not slow to embrace it. ${ }^{195}$

His religious views come through when he translates "les erreurs de Wiclef" by "Wickliff's opinions". But, says Matthiessen "Florio's greatest gift was the ability to make his book come to life for the Elizabethan imagination", 196 and "everything that Florio does to Montaigne is calculated to bring the Essays closer to the spirit of his time". ${ }^{197}$ Writing just a few years after Matthiessen, Frances Yates makes some perceptive remarks about the Florio translation:

It is somewhat ironical that Montaigne, who was one of the first great writers in a modern tongue to write in a modern manner, using words simply as the exact clothing of his thought and relying for beauty of style solely upon the aptness of the word to the thought and upon emotional rhythm, should have had as his translator one to whom elaborate rhetorical word-pattern was an instinctive necessity and a habit deeply ingrained by long training. ${ }^{198}$

While modern criticism has shown that Montaigne uses words far from simply as "the exact clothing of his thought", the distinction made by Yates is still valid. She goes on to say that

It is this inherent instinct of his for rhetorical expansion which is at the bottom of the most obvious characteristic of his translation, which is

${ }^{193}$ F. O., Matthiessen, Translation, an Elizabethan Art, Cambridge, Harvard University Press, 1931, p. 121

194 Ibid., p. 127.

195 Ibid., p. 137.

196 Ibid., p. 141.

197 Ibid., p. 151.

${ }^{198}$ Frances Yates, John Florio, the life of an Italian in Shakespeare's England, Cambridge, Cambridge University Press, 1934, p. 227. 
that he hardly ever renders one French word by one English word if he can possibly work in two or more than two. ${ }^{199}$

The personality of the translator intrudes on every page of his translation. Yates refers to him as "the least self-effacing of translators" and says "that in many passages Montaigne's opinion reaches the English reader coloured by Florio's prejudices". ${ }^{200}$ These "politicoreligious" prejudices are highly relevant for the purposes of the present study, because I hope to show that Shakespeare's "borrowing" of Florio's translation does not necessarily indicate that he was quoting Montaigne's thought or ideas in all their fullness. This is particularly true in the case of Des Cannibales.

The only substantial use of Florio's text in Shakespeare is the short speech of Gonzalo in Act II scene $\mathrm{i}$ in The Tempest. It has often been seen as ironic, on account of the criticisms heaped upon Gonzalo by Sebastian and Antonio, who mock his musings and pour scorn upon his idealism. The mockers, however, are the very characters who represent treachery and evil in the play, so that condemnation from their mouths may not necessarily be taken at face value. Rather than enter into that debate, I will look at the Florio translation of the Montaigne passage in detail, with a view to determining if there is any shift in perspective from one to the other:

$\begin{array}{ll}\text { C'est une nation, diroy je à Platon, } & \text { It is a nation, would I answer } \\ \text { en laquelle il n'y a aucune espece } & \text { Plato, that hath no kinde of } \\ \text { de trafique; nulle cognoissance de } & \text { traffike, no knowledge of Letters, } \\ \text { lettres; nulle science de nombres; } & \text { no intelligence of numbers, no } \\ \text { nul nom de magistrat, ny de } & \text { name of magistrate, nor of } \\ \text { superiorité politique; nul usage de } & \text { politike superioritie; no use of } \\ \text { service, de richesse ou de } & \text { service, or riches or of povertie; } \\ \text { pauvreté; nuls contrats; nulles } & \text { no contracts, no successions, no } \\ \text { successions; nuls partages; nulles } & \text { dividences, no occupation but } \\ \text { occupations qu'oysives; nul } & \text { idle; no respect of kinred, but } \\ \text { respect de parenté que commun; } & \text { common, no apparell but } \\ \text { nuls vestemens; nulle agriculture; } & \text { naturall, no manuring of lands, } \\ \text { nul metal; nul usage de vin ou de } & \text { no use of wine, corne, or mettle. } \\ \text { bled. (I, 31, 206) } & (\mathrm{I}, 30,102) 201\end{array}$

The text of The Tempest follows Florio quite closely:

199 Ibid., p. 228

200 Ibid., p. 234

201 The Montaigne text used is the Villey-Saulnier edition (Paris, PUF, 1988). The Florio text is the 1603 edition (London, Val. Sims for Edward Blount). 
I' th' com monwealth I would by contraries

Execute all things; for no kind of traffic

Would I admit; no name of magistrate;

Letters should not be known; riches, poverty,

And use of service, none; contract, succession

Bourn, bound of land, tilth, vineyard, none;

No use of metal, corn, or wine, or oil;

No occupation; all men idle, all;

And women too, but innocent and pure:

No sovereignty;

(II.i.143-152)

The Florio translation appears at first sight to be very exact and a faithful reproduction of the original French. But even in this short extract there are several divergences from the text of the Essais. First of all the "diroy je à Platon" becomes "would I answer Plato", which implies that there is a debate going on, in which Plato has put forward his view of the ideal society, and the English text is retorting in the language of debate and dialogue. This opposition is not present to the same extent in the French text. It is, however, typical of the lively and interpretive translation of Florio. Secondly Montaigne says that "il n'y aucune espece de trafique", which is rendered by "that hath no kinde of traffike", indicating ownership, possession, which is perhaps more evaluative than the purely neutral and objective "il n'y a". Thirdly, Montaigne's "nulle science de nombres" is changed to "no intelligence of numbers", which is not quite the same thing. Even if we take Michael Screech's version in his translation "no knowledge of numbers" (whereas most of the other translators keep "no science of numbers") there is still a distinction to be made between science or system on the one hand; knowledge (familiarity) on the other; and "intelligence" or understanding, which is the Florio version. In other words, Florio appears to overestimate the lack of understanding of the natives, in order to render his text more dramatic, and more conflictual.

Fourthly there is the famous phrase "nulles occupations qu'oysives" which Florio translates as "no occupation but idle" and which Shakespeare takes a step further with "all men idle, all". Where Montaigne qualifies the "occupations" as "oisives", (the grammatical agreement underlying the connection between the two words), Florio sets up an opposition: not occupied, but idle, whereas later translators all have a different approach: "no occupations but leisure ones" (Frame); "only leisurely occupations" (Cohen); "no employments but those of leisure" (Cotton). Finally there is the translation of "nuls 
vetements" by "no apparell but naturall". Florio frequently adds words without any justification on the grounds of the original text. He is especially prone, as Matthiessen has pointed out to doubling words, a trait already present in the Essais, but increased many times by Florio. In this case the contrast between culture and nature is highlighted, further dramatising the English text. There is a further resonance to his own text, where "no occupation but idle" is echoed by "no apparell but naturall", creating a flow and unity in the translated text which is new, and therefore different from the original. The broken rhythm of the French text is softened, made more elegant. In other words it is less authentic than the original, and more "cultured".

The above passage is translated in an accurate manner, by Florio's standards, when we look only at the text itself. There are indeed differences which may be interpreted as being based on cultural assumptions and values. But translation is more than just the rendering of one text by another. Context, as much as text, is another means by which meaning is transferred, and here the problems with translation become more complex, because contexts exist at every level, both in the text itself, in the referential world to which each text relates, and to the intertextual resonances of both original and translated texts. That is why Derrida says so appropriately that "un contexte n'est jamais absolument déterminable, ou plutôt [...] sa détermination n'est jamais assurée ou saturée". ${ }^{202}$ The contexts of Des Cannibales have been outlined in several excellent articles. In many cases the historicopolitico-religious contexts of the sixteenth century have been identified, explained and analysed. Frank Lestringant, for example, has shown how the essay is in fact "un bricolage des plus étourdissants", consisting of borrowings from the most diverse and often contradictory sources. ${ }^{203}$ Gérard Defaux has shown how the essay, beyond its satire of the politics of colonialism and expansion of Christian nations, is also "un prétexte à l'exercice du jugement". ${ }^{204}$ Both of these articles attempt to put the essay into its broader context, whether it be source materials used, or the overall intellectual project of Montaigne. But I will start by looking at a recent interpretation of the essay, that of George Hoffmann, who puts forward an ingenious and tightly argued case for a

\footnotetext{
202 Jacques Derrida, Marges de la philosophie, Paris, Les Éditions de Minuit, 1972, p. 369.

203 "Le Cannibalisme des Cannibales", p. 37.

204 "Un Cannibale en haut de chausses", p. 935.
} 
religious reading of Des Cannibales. Hoffmann argues that Montaigne's "ideal reader" could have seen in the essay references to well-known Protestant satirical writings on the Eucharist. The third criticism that the "Indian" is quoted as expressing at the end of the essay, and which Montaigne claims he has "forgotten", could well be the cannibalism of those who believe that they are eating the body of Christ in the Eucharist. Bearing in mind the notorious anti-Catholicism of Florio, could we expect to find in his translation any hint that he was alive to this possible meaning of the essay? It is far more likely that he would have been aware of the religious dimension of the essay, rather than the anthropological ones, especially in view of his own religious views. If he had identified any hint of polemical intention in the text of Des Cannibales, surely he would have exploited it to the full. Let us look therefore at some of the key translations:

Ils ne boyvent pas lors, comme Suidas dict de quelques autres peuples d'Orient, qui beuvoient hors du manger; ils boivent à plusieurs fois sur jour, et d'autant. Leur breuvage est faict de quelque racine, et est de la couleur de nos vins clairets. Ils ne le boyvent que tiede: ce breuvage ne se conserve que deux ou trois jours; il a le goust un peu piquant, nullement fumeux, salutaire à l'estomac, et laxatif à ceux qui ne l'ont accoustumé: c'est une boisson tres-agreable à qui y est duit. Au lieu du pain, ils usent d'une certaine matiere blanche, comme du coriandre confit. J'en ay tasté: le goust en est doux et un peu fade. (I, 31, 207)
They drinke not at meat, as Suidas reporteth, of some other people of the East, which dranke after meales but drinke many times a day, and are much given to pledge carowses. Their drinke is made of a certaine root, and of the colour of our Claret wines, which lasteth but two or three daies; they drinke it warme : it hath somewhat a sharpe taste, [...] wholesome for the stomack, nothing heady, but laxative for such as are not used unto it, yet verie pleasing to such as are accustomed unto it. In stead of bread, they use a certaine white composition, like unto Corianders confected. I have eaten some, the taste whereof is somewhat sweet and wallowish. (I, 30, 103)

Here again Florio appears at first sight to follow with great fidelity the French text. However, there are about ten significant changes, some of which are more precise, others less precise than the French. Thus "lors" becomes "at meat", and "hors du manger" becomes "after meales". The shift from the time indicator to the activity indicator is perhaps typical of the more concrete tendencies of the English language, because "at meat" is a particularly vivid representation of the meal-time of these 
people. On the other hand, "peuples d'Orient" (plural) is translated by "people of the East" (singular), a generalisation replacing the more concrete and plural word of the French. Montaigne's sensitivity to the diversity and variety of different societies is not shared by Florio, to whom they are all merely "people" in general, as opposed to distinct social groupings, each with their own customs and social organisation. Then Florio adds the word "but", thereby creating more overt opposition between the activities referred to, while Montaigne's text flows more freely, indicating unity, rather than opposition. But surely Florio lets his pen run away with him when he translates "et d'autant" by "and are much given to pledge carowses". One might well follow Matthiessen here when he says: "Florio is no longer translating, but envisaging the scene anew". ${ }^{205}$ The preference for the concrete is obvious throughout the Florio text, but there are times when it gives a different, rather than a faithful reading of the original. There is also perhaps an element of moral judgment here, with Florio suggesting that the natives are giving way to their basic instincts, while Montaigne indicates in a more objective fashion that they drink a lot. The change in the word order of "Ils ne le boyvent que tiede: ce breuvage ne se conserve que deux ou trois jours" for "which lasteth but two or three daies; they drinke it warme" may be effected for purely stylistic reasons. The slightly staccato rhythm of the French is broken up to some extent by Florio, who tries to smoothen the crude, improve on the naturally disjointed French text. But this very stylistic "improvement" is also indicative of a difference in perspective of the two writers. Montaigne attempts to portray the natural society of the cannibals as he has come to know it, through books and eye-witnesses. Florio is more concerned with the aesthetic, stylistic nature of his text, even if in the process he creates a more refined and polished image of the natives than had appeared in the French text which he was translating. There may therefore, to some extent, be the beginnings of a dialogue between the two writers over the respective values of Art and Nature (which of course is also one of the central themes of The Tempest).

Another change in the word order occurs with the words "heady but", which come after the phrase "wholesome for the stomack". This slight reorganisation of the English text indicates again the desire of Florio to create surprise through the use of opposition and contrast.

205 Translation, an Elizabethan Art, p. 147. 
Whereas Montaigne's French is deliberately flat and inexpressive on this occasion, as if he is attempting to remain on the purely descriptive level, without becoming involved through the statement of his own perspective, the English translation is quite different. Florio's "yet very pleasing" continues to adapt the original, adding expressions of contrast and opposition which do not appear in the French. Then the words "matiere blanche" are translated by "a certain white composition". Other translators use "matter" (Cotton), "substance" (Frame), "product" (Screech), "material" (Trechmann) and "stuff" (Cohen). The word "composition" again emphasises manufacture, artifice, as opposed to the more natural sounding "matiere blanche". It would thus appear that Florio is either imposing his own perspective of surprise on the text being translated, or else is adapting the text so that it reflects his own reaction to reading the original. In either case he is changing the text in such a way that it diverges from the French in a significant fashion.

The analysis of this last extract would seem to show that Florio is far from being an "ideal reader" of Montaigne. There does not appear to be any evidence to indicate that he saw religious significance, perhaps relating to the bread and wine of the Mass in the Montaigne text. I do not intend to suggest by this observation that George Hoffmann's interpretation is in any way unsound. But it would seem that Florio's translation is at times lacking in the subtlety and finesse that were present in the Montaigne text. In addition to this lack of sensitivity, there is a tendency to write from his own perspective rather than from that of Montaigne, and even to impose (in certain areas) his own values on the reader of the English text.

A passage from the early part of the essay is relevant here:

Cet homme que j'avoy, estoit homme simple et grossier, qui est une condition propre à rendre veritable tesmoignage: car les fines gens remarquent bien plus curieusement et plus de choses, mais ils les glosent; et, pour faire valoir leur interpretation et la persuader, i ne se peuvent garder d'alterer un peu l'Histoire: ils ne vous representent jamais les choses pures, ils les inclinent et
This servant I had, was a simple and rough-hewen fellow: a condition fit to yield a true testimonie. For, subtile people observe things more exactly, but they amplifie and glose them: and the better to perswade, and make their interpretations of more validitie, they cannot chuse but somewhat alter the storie. They never represent things truly, but fashion maske them according to the visage they saw them in; and to 
masquent selon le visage qu'ils leur ont veu; et, pour donner credit à leur jugement et vous y attirer, prestent volontiers de ce costé là à la matiere, l'alongent et l'amplifient. Ou il faut un homme tres-fidelle, ou si simple qu'il n'ait pas dequoy bastir et donner de la vray-semblance, des inventions fauces; et qu n'ait rien espousé. (I, 31, 205) purchase credit to their judgement, and draw you on to believe them, they commonly adorne, enlarge, yea, and hyperbolize the matter. Wherein is required either a most sincere Reporter, or a man so simple, that he may have no invention to build upon, and to give a true likelihood unto false devices, and be not wedded to his owne will. (I, 30, 101)

Montaigne is referring here to eye witnesses of events and situations and has chosen what Terence Cave has called a "maximally natural eyewitness". ${ }^{206}$ But much of what he says could also be applied to Florio, who is translating his text, and who is giving his own slant to the situation being described. As reader and translator, Florio is a subtle interpreter of the Montaigne text, and he occasionally sees more things in the text, occasionally fewer. Even in this extract, we can see how Florio imposes his vision on the text: Montaigne refers to "cet homme", which becomes "this servant", a very minor change, but one which alters the relationship between the two people. Of course the word "homme" is often used to mean "servant", but the context in which it appears allows ambiguity. By avoiding the term "servant", Montaigne again maintains a degree of distance between them, a distance which is narrowed by Florio's choice, which indicates a relationship of superior to inferior which does not appear in the French text. Then "bien plus curieusement et plus de choses" becomes "more exactly".

The "plus de choses" is transformed by Florio into the verb "amplifie", thereby changing the objective "more things" into the subjective actions of the observer. Montaigne says that the sophisticated man sees more things. Florio says that the sophisticated man amplifies what he sees, which is by no means the same thing. There is a difference of perspective here which is relevant to the overall themes of Des Cannibales and The Tempest.

The relationship between the eyewitness and the content of the essay is explored by Edwin Duval who quotes the passage I have just dealt with, and makes the point that

\footnotetext{
206 Terence Cave, The Cornucopian Text: problems of writing in the French Renaissance,
} Oxford, Clarendon Press, 1979, p. 301. 
the "simple" eyewitness [...] resembles in his unassuming naturalness the "naifveté" of the Brazilian "sauvage" who freely obeys the uncorrupted laws of Nature. And conversely the "fines gens" of this passage clearly resemble the corrupted Europeans who have abandoned Nature for Art. 207

Duval goes on to contrast this "simple eyewitness" with the obtuseness of Montaigne's interpreter in the latter part of the essay, and claims that "What makes the interpreter inadequate is precisely what made the eyewitness so reliable". He speaks of the "transvalorization" of the ideas of Art and Nature, along with the terms "barbare" and "sauvage", and shows how this process becomes

a demonstration of a lesson that is nowhere stated but everywhere present: its shifting perspective and transvalorizations illustrate, in the text of the essay itself, the Pyrrhonian premise that "et nous, et nostre jugement, et toutes choses mortelles, vont coulant et roulant sans cesse". 208

The key words which Duval examines in order to contrast the naive eyewitness quoted in the earlier part of the chapter with the point of view expressed towards the end of Des Cannibales are as follows:

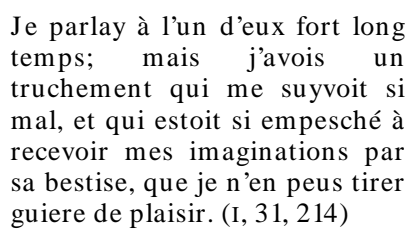

I talked a good while with one of them, but I had so bad an interpreter, who did so ill apprehend my meaning, and who through his foolishnesse was so troubled to conceive my imaginations, that I could draw no great matter from him. (I, 30, 106)

Firstly the temporal indicator "fort long temps" is stressed by Montaigne, who places it at the end of the clause. This is rendered by Florio as "a good while", in the middle of the clause, and much more vague than the French. It is a more casual, less intense signifier than the language used by Montaigne. Secondly the "un truchement qui me suyvoit si mal" is translated by "so bad an interpreter, who did so ill apprehend my meaning". Here the interpreter, who in the French text merely "me suyvoit si mal", becomes doubly bad: he is "so bad an interpreter" and also "did so ill apprehend my meaning" which is more of an amplification, an intensification, a development of the French

${ }^{207}$ Edwin Duval, "Lessons of the New World: Design and Meaning in Montaigne's Des Cannibales and Des Coches", Yale French Studies 64 (1983) p. 95-112.

208 Ibid., p. 104. 
text. The stupidity of the interpreter is thereby exaggerated somewhat, and instead of the descriptive words of Montaigne, the English text borders on the judgmental and appears to create a greater distance between the European interviewer and the "savage" interviewee. Finally the "je n'en peus guiere tirer de plaisir" is translated as "I could draw no great matter from him". Here again there is a shift in perspective. Montaigne states that he was dissatisfied at the contribution of the interpreter, while Florio judges that the cause for this dissatisfaction was that the interpreter was incapable of communicating serious ideas. The shift in emphasis from the emotional reaction of the essayist to the inadequacy of the interpreter indicates that the Italian translator has a tendency to assess and evaluate the natives in a way that Montaigne studiously avoids.

This difference in approach can also be seen when we examine André Tournon's analysis of Des Cannibales. ${ }^{209}$ The author demonstrates how Montaigne adopts a paradoxical approach to several terms such as "barbarie" and "sauvagerie", and how the "natural" natives have their own culture, demonstrated in the following passage describing the putting to death of their enemies:

[il] fait une grande assemblée de ses cognoissans: il attache une corde à l'un des bras du prisonnier, par le bout de laquelle il le tient, esloigné de quelques pas, de peur d'en estre offencé, et donne au plus fidèle de ses amis l'autre bras à tenir de mesme; et eux deux, en presence de toute l'assemblée, l'assomment à coups d'espée. Apres cela, ils le rostissent et en mangent en commun et en envoient des lopins à ceux de leurs amis qui sont absens. Ce n'est pas, comme on pense, pour s'en nourrir, ainsi que faisoient anciennement les Scythes: c'est pour representer une extreme vengeance. (I, 31, 209) sommining a great assembly of his acquaintance; tieth a corde to one of the prisoners armes, by the end whereof he holds him fast, with some distance from him, for feare he might offend him, and giveth the other arme, bound in like manner, to the dearest friend he hath, and both in the presence of all the assembly kill him with swords: which done, they roast and then eat him in common, and send some slices of him to such of their friends as are absent. It is not, as some imagine, to nourish themselves with it (as anciently the Scithians wont to doe), but to represent an extreme and inexpiable revenge. (I, 30, 103104)

209 André Tournon, Montaigne, La glose et l'essai, Lyon, Presses Universitaires de Lyon, 1983, p. 217-221. 
Tournon comments that this is the description of "une cérémonie communautaire et symbolique, moins cruelle bien sûr que les supplices dont les Européens se donnent le spectacle, mais non pas plus naturelle". 210 What is striking here is the fidelity with which Florio translates. Scarcely any deviation exists from the wording of the French text, to such an extent that one wonders why the normally ebullient and creative Italian could so submit himself to the text of the original. It is of course the depiction of what we would normally call "savagery", and is a literal depiction of cannibalism. Can it be that Florio is so in tune with his contemporary ideology which despises the barbarism and primitivism of the savages, that he is unable to see any of the subtle irony and paradox which even in France has only recently been identified? He even undertranslates one phrase: "kill him with swords" is somewhat flat compared to the French "l'assomment à coups d'espée", which has intimations of the rhythmical blows struck in this ritualised killing. If anything, this style of translation indicates (as we saw in the discussion of Hoffmann's interpretation) that Florio was unaware of the complicated levels of meaning in the Montaigne text, and that his translation was infused more with his own pre-judgments than with the full subtleties of the French essayist.

Philippe Desan's fascinating analysis of the economic dimension of Des Cannibales is perhaps more likely to have some resonances in the Florio translation. He suggests that what attracts Montaigne in the primitive societies is their lack of commercial concerns:

L'auteur des Essais croit percevoir chez les Cannibales les derniers vestiges de la noblesse Il transpose inconsciemment les valeurs nobiliaires au sein de la société cannibale qui s'offre désormais comme le seul exemple possible d'une société non encore corrompue par le mode de production capitaliste et l'éthique bourgeoise qui accompagne l'économie de marché. ${ }^{211}$

But even here, Florio is lukewarm, and translates Montaigne's glowing portrayal of the cannibal warfare: "Leur guerre est toute noble et genereuse" by "Their warres are noble and generous", omitting to translate the reinforcing "toute". Florio's version shows more concern with the rhythm of the phrase than with the notion that the cannibals

210 Ibid., p. 218

211 Montaigne, les Cannibales et les Conquistadores, p. 48 
may have a nobility that is fast disappearing in European societies under the pressure of increasing bourgeois and commercial values.

It would seem to be particularly in the realm of "colonialism" that Florio betrays his own opinions in this essay. When speaking of the social customs of the cannibals, Montaigne consistently maintains an apparent distance and objectivity from the events he is describing. This is not the case with Florio, as the following extract shows:

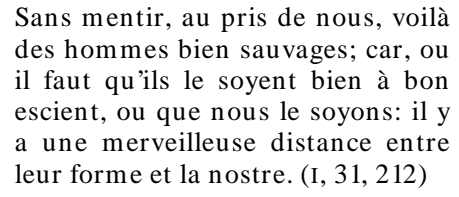

Sans mentir, au pris de nous, voilà des hommes bien sauvages; car, ou il faut qu'ils le soyent bien à bon escient, ou que nous le soyons: il y a une merveilleuse distance entre leur forme et la nostre. (I, 31, 212)

Surely in respect of us these are very savage men; for either they must be so in good sooth, or we must be so indeed: There is a wondrous distance betweene their forme and ours. (I, 30, 106)

Unusually for Florio, this is a rather flat translation. Indeed it is so lacking in conviction that it lacks any of the ironic implications of the French: "voilà des hommes bien sauvages", with its implication that it is only from our perspective that this "sauvagerie" exists, and not in reality. The relativism which is apparent in the French is far less evident in the translation. And the addition of "indeed" appears to twist the irony away from the judgment of the "sauvages" towards the almost unthinkable notion that it is we who are barbarous: "we must be so indeed".

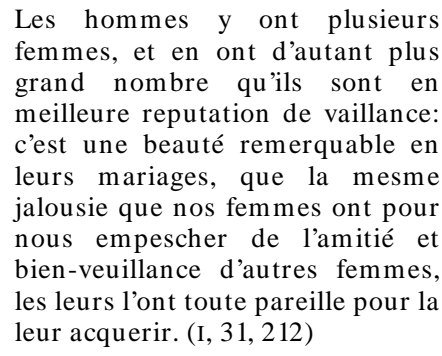

Their men have many wives, and by how much more they are reputed valiant so much the greater is their number. The manner and beautie of their marriages is wondrous strange and remarkable: For, the same jealousie our wives have to keepe us from the love and affection of other women, the same have theirs to procure it. (I, 30, 106)

Once again we see the creation of distance by the use of "their" in the first line, where Montaigne uses the definitive article. And Florio cannot withhold his amazement when he adds in "wondrous strange and remarkable" where Montaigne had only "remerquable". And where Montaigne uses the reinforcer "toute pareille" to represent similarity between us and them, the English text simply repeats the word "same". Where is the rhetoric and the amplification of the greater part of the 
Florio text? It does appear that his translation is here influenced strongly by a sense of colonialism which is quite absent from the original French.

The sobre and objective style of Montaigne's descriptions of the cannibals has already been pointed out by Gérard Defaux. Having quoted lengthy extracts from the essay he comments:

Style autant qu'on le voudra pointilliste, dépouillé, linéaire et ponctuel, cumulatif et clinique, qui dit clairement son refus d'interpréter. ${ }^{212}$

Although this apparent transparency and simplicity itself derives from classical rhetorical devices, it is still instructive to compare the French phrases with their English translations. The first phrase quoted by Defaux is translated as literally as it is possible to do:
ils sont assis le long de la mer [...] Ils ont grande abondance de poisson et de chair $[\ldots]$
They are seated alongst the sea-coast [...] They have great abundance of fish and flesh [...] Their buildings are
Leurs bastimens sont fort longs
very long $[\ldots]$
They have a kinde of wood so hard
Ils on du bois si dur qu'ils en coupent et en font leurs espées et des gril à cuire leur viande.
(I, 31, 207)
that ryving and cleaving the same, they make blades, swords and grid- irons to broile their meat with. (I, $30,102-103)$

The flat style of Montaigne is reproduced initially by his translator. It is only in the sentence about the wood that Florio departs substantially from the French: "a kind of wood" is already an amplification of "du bois", but "qu'ils en coupent" becomes "ryving and cleaving the same", and the word "blades" is added. The need the translator feels to gloss, to explain, to interpret the original shows that he wants to highlight the strangeness of the situation being described, and in the process he departs from the deliberately neutral tone of Montaigne.

The whole essay could be analysed along these lines, but in the time available I can only highlight some of the major characteristics of this translation. A few more examples will confirm the tendency that has already been noted:

c'est une beauté remerquable en leurs mariages $(\mathrm{I}, 31,212)$
The manner and beautie of their mariages is wondrous strange and remarkable (I, 30, 106)

212 "Un Cannibale en haut de chausses", p. 946. 
Again the expansion of the English text leads to a difference of perspective. The neutral "leurs marriages" becomes "the manner and beautie of their marriages", and "remerquable" becomes "wondrous strange and remarkable". There is no semantic justification for the additions, apart from the fact that Florio continues to interpret the situation from his own perspective, that of the European considering the strangeness of the barbarians.

A final example is the reference to the language of the cannibals:

Leur langage, au demeurant, c'est un doux langage et qui a le son aggreable, retirant aux terminaisons Grecques. (I, 31, 213)

Florio's translation is interesting in the context of Stephen Greenblatt's study of linguistic colonialism in the sixteenth century. "Un doux langage" becomes "a kinde of pleasant speech" and "retirant" becomes "[hath] some affinite with". Both of these expressions indicate a condescending, almost surprised, and to some extent a colonialist view of these barbarian languages, a view that is referred to in The Tempest, when Caliban says:

You taught me language; and my profit on't

Is, I know how to curse. The red plague rid you

For learning me your language!

(I.ii.364-366)

Caliban here expresses a profound truth: that "whatever the natives may have actually thought and said has been altered out of recognition by being cast in European diction and syntax". ${ }^{213}$ A comparison of the Montaigne text and the Florio text shows just how much the perspectives of each differed with regard to the language of the natives.

In many respects Florio interpreted Montaigne's text with what Francis Barker and Peter Hulme call "unspoken colonialist assumptions". ${ }^{214}$ Such assumptions existed at the time of Shakespeare, but they still persist today. For example, Frank Kermode refers in his Arden Tempest to the "treachery" of the natives, after initial hospitality

213 Stephen J. Greenblatt, "Learning to Curse: Aspects of Linguistic Colonialism in the Sixteenth Century", in First Images of America, the impact of the New World on the Old, vol. 2, Berkeley, University of California Press, 1976, p. 571

214 "Nymphs and Reapers heavily vanish", p. 201. 
has been shown towards the invaders. ${ }^{215}$ Of course The Tempest is not a full-blooded exposition of colonialist ideology. As Paul Brown says, the play

declares no all-embracing triumph for colonialism. Rather it serves as a limit text in which the characteristic operations of colonialist discourse may be discerned - as an instrument of exploitation, a register of beleaguerment and a site of radical ambivalence. ${ }^{216}$

As with any great writer, there are few simple readings that can do justice to the text. That there is colonialist discourse in the play is indisputable. But, argues Meredith Anne Skura, it is no more justifiable to "flatten the text into the mold of colonialist discourse and eliminate[s] what is characteristically 'Shakespearean' in order to foreground what is 'colonialist' than it is to ignore colonialist discourse entirely". 217

What can we say, then, about the contribution of Florio's translation of Montaigne to Shakespeare's The Tempest? From the extracts which we have examined, the following conclusions may be drawn. First, that while Florio's translation is a very good one, and brings to life many aspects of the Essais of Montaigne for Elizabethan readers, it does carry with it a certain ideological baggage, sometimes religious, sometimes political, sometimes social and cultural. Second, that the translation of Des Cannibales betrays, in some sections, elements of colonial discourse, either implied or explicit, and that these elements were not present in the original French text. Third, that if, as appears certain, Shakespeare borrowed certain of his expressions, attitudes and ideas from his reading of the Florio Montaigne, it is reasonable to assume that he incorporated the Florio ideology, rather than the Montaigne philosophy, into his play. Finally we may reasonably argue that the discourse of colonialism in The Tempest does not derive directly from Des Cannibales, which is one of the great anti-colonial texts of literature, but that it may well adopt some of the perceptions and attitudes that find their expression in the Florio translation.

Philip HENDRICK

University of Ulster

215 William Shakespeare, The Tempest, ed. Frank Kermode, London, Methuen, 1954, p. 67. 216 "This thing of darkness I acknowledge mine", p. 68.

217 "Discourse and the Individual", p. 47. 